\title{
MODEL PEMBELAJARAN EXPERIENTIAL KOLB DENGAN VISUALISASI VIRTUAL UNTUK MENINGKATKAN PEMAHAMAN KONSEP MAHAMAHASISWA TEKNIK UNMA TEKNIK MESIN PADA MATA KULIAH FISIKA DASAR II MATERI LISTRIK
}

\author{
Eidelweis Dewi Jannati ${ }^{1}$, Yudi Samantha ${ }^{2}$ \\ Teknik Mesin, Fakultas Teknik Universitas Majalengka \\ email :eidelweis_unma@yahoo.com ${ }^{1}$,yudisamantha@gmail.com ${ }^{2}$
}

\begin{abstract}
ABSTRAK
Berdasarkan hasil studi kasus yang peneliti lakukan pada salah satu Perguruan Tinggi Swasta di Majalengka, diperoleh hasil tes pemahaman konsep mahasiswa pada mata kuliah fisika dasar dengan nilai rata-rata 5,5. Dengan demikian dapat dikatakan bahwa pemahaman konsep siswa masih tergolong rendah. Hal ini dikarenakan model pembelajaran yang dosen terapkan. Model pembelajaran yang digunakan yaitu model pembelajaran konvensional, sehingga mahasiswa cenderung pasif. Akibatnya, pemahaman konsep mahasiswa rendah. Untuk itu, diperlukan model pembelajaran yang tepat. Model experiential Kolb dengan visualisasi virtual salah satu alternatif yang tepat, karena mahasiswa dituntut aktif dan kreatif membangun pengetahuannya. Tujuan penelitian ini adalah untuk mengetahui peningkatan pemahaman konsep setelah diterapkan model experiential Kolb dengan visualisasi virtual. Desain penelitian Control Group Pretest-Posttest Design, teknik Mesin semester IIA sebagai kelas eksperimen.
\end{abstract}

Kata Kunci: Model Pembelajaran Experiential Kolb, Visualisasi Virtual, Pemahaman Konsep.

\section{PENDAHULUAN}

Proses pembelajaran IPA menekankan pada pemberian pengalaman langsung untuk mengembangkan kompetensi agar peserta didik menjelajahi dan memahami alam sekitar secara ilmiah. Pendidikan IPA diarahkan untuk memperoleh pemahaman yang lebih mendalam tentang alam sekitar (Depdiknas, 2006). Salah satu cabang IPA adalah Fisika. Oleh karena itu mahasiswa perlu memahami konsep Fisika secara lebih mendalam agar mampu menyelesaikan masalah atau mengaplikasikannya dalam kehidupan seharihari. Pemahaman konsep merupakan pemahaman tentang hal-hal yang berhubungan dengan konsep yaitu arti, sifat, dan uraian suatu konsep dan juga kemampuan dalam menjelaskan teks, diagram, dan fenomena yang melibatkan konsep-konsep pokok yang bersifat abstrak dan teori-teori dasar sains.

Selain itu, sains merupakan sekumpulan ilmu-ilmu serumpun yang terdiri atas Biologi, Fisika, Geologi dan Astronomi yang berupaya menjelaskan setiap fenomena yang terjadi di alam (Liliasari, 2005). Sains berkaitan dengan cara mencari tahu tentang alam secara sistematis, sehingga sains bukan hanya penguasaan kumpulan pengetahuan yang berupa fakta-fakta, konsep-konsep, atau prinsipprinsip saja tetapi merupakan suatu proses penemuan (Depdiknas, 2003).

Seiring dengan itu, KTSP memberi penekanan atau memfokuskan pada mahasiswa sehingga akan membawa konsekuensi yang luas. Selain mahasiswa menguasai materi fisika, mahasiswa diharapkan juga dapat mengembangkan jati dirinya, mengenal lingkungannya, dapat bersosialisasi dengan lingkungan dan juga peka terhadap lingkungan serta tahu akan hak dan kewajibannya. Dengan demikian, belajar tidak hanya berlangsung di dalam lingkungan perguruan tinggi, tetapi juga dapat berlangsung di luar perguruan tinggi, di masyarakat, alam sekitar, untuk dapat mengembangkan kreativitas mahasiswa sendiri. Disini mahasiswa ditekankan harus mampu menjelaskan fenomena-fenomena fisis dalam kehidupan sehari-hari, sehingga dengan itu pembelajaran menjadi bermanfaat, tidak hanya mendengarkan ceramah dari dosen akan tetapi mereka mengetahui atau mampu menjelaskan fenomena fisis dalam kehidupan sehari-hari.

Berdasarkan hasil studi kasus yang peneliti lakukan pada salah satu Perguruan 
Tinggi Swasta di Majalengka, diperoleh hasil tes pemahaman konsep mahasiswa pada mata kuliah fisika dengan nilai rata-rata 5,5. Dengan demikian dapat dikatakan bahwa pemahaman konsep Mahasiswa masih tergolong rendah. Hal ini disebabkan mahasiswa saat pembelajaran di kelas hanya mendengarkan dosen mengajar, mengerjakan soal-soal yang diberikan oleh dosen. Dengan demikian, mahasiswa belajar lebih pasif. Model pembelajaran yang biasa diterapkan ialah model konvensional dimana dosen lebih banyak menggunakan teknik ceramah serta menekankan pada latihan pemecahan soal. Model tersebut dipilih karena lebih sederhana dalam pelaksanaannya sehingga tidak memerlukan persiapan khusus dalam mengimplementasikannya dan tidak memerlukan waktu yang cukup lama. Namun para pengajar mengakui model pembelajaran tersebut memiliki banyak sekali kekurangan.

Garis besar dari apa yang diungkapkan salah satu pengajar, diperoleh hasil:

A. Mahasiswa sulit memahami konsepkonsep dari materi yang disampaikan.

B. Mahasiswa bersifat pasif, hanya mendengarkan ceramah dari pengajar. Hal ini keterampilan-keterampilan mahasiswa tidak terlatih, sehingga konsep yang sudah di terima mudah dilupakan.

Dari pernyataan diatas mahasiswa tidak mampu memahami konsep. Padahal, pembelajaran sains akan bermakna apabila mahasiswa mampu menghubungkan fenomena baru ke dalam struktur pengetahuan mereka. Hal tersebut diperkuat pernyataan, Mata kuliah akan tambah berarti jika Mahasiswa mempelajari materi yang disajikan melalui konteks kehidupan mereka dan menemukan arti dalam proses pembelajaran sehingga belajar akan lebih bermakna dan menyenangkan (Sanjaya, 2009). Sementara itu menurut Ausubel bahan subjek yang dipelajari Mahasiswa mestilah "bermakna" (meaningfull). Pembelajaran bermakna merupakan suatu proses mengaitkan informasi baru pada konsepkonsep relevan yang terdapat dalam struktur kognitif seseorang. Struktur kognitif ialah fakta-fakta, konsep-konsep, dan generalisasigeneralisasi yang telah dipelajari dan diingat mahasiswa.
Salah satu model pembelajaran yang mendukung untuk menyelesaikan permasalahan diatas yaitu model pembelajaran experiential Kolb (Manolas, 2005). Model pembelajaran ini menyajikan empat tahapan yaitu pengalaman kongkrit (concrete experience) bagi mahasiswa sebagai awal pembelajaran. Pada tahap ini mahasiswa secara individu menekankan pada pembelajaran berpikir terbuka dan kemampuan beradaftasi daripada pendekatan sistematik pada situasi masalah. Tahap kedua yaitu pengamatan reflektif (reflective observation). Pada tahap ini mahasiswa mengamati demonstrasi sederhana dengan menampilkan visualisasi virtual serta mencoba mengeluarkan pendapat mengapa dan bagaimana hal tersebut terjadi. Tahap ketiga yaitu konsepsi abstrak (abstrak conceptualization). Pada tahap ini menjadi mengerti konsep secara umum dengan tahap pertama dan kedua sebagai acuan. Konsepsi abstrak mengharuskan mahasiswa untuk menggunakan logika dan pikiran untuk memahami situasi dan masalah. Kemudian diselesaikan melalui percobaan aktif (active experimentation). Pada tahap ini mahasiswa menggunakan teori yang mereka dapat selama konsepsi abstrak untuk membuat prediksi. Melalui pembelajaran ini diharapkan dapat membangun konsep yang bermakna dan kepercayaan diri dalam memecahkan masalah dan membuat keputusan yang cermat.

Penelitian terhadap model pembelajaran experiential Kolb dilakukan oleh Manolas (2005) menunjukkan bahwa model pembelajaran experiential Kolb dapat menstimulasi mahasiswa untuk memilih pembelajaran dan menantang mereka untuk membangun kemampuan dalam mengefektifkan pemikiran dan pemecahan masalah. Untuk itu, peneliti bermaksud menerapkan suatu pembelajaran yang melibatkan mahasiswa untuk mencari pengetahuannya sendiri dan pemahaman konsep melalui model pembelajaran tersebut pada konsep Listrik.

Salah satu konsep yang ada dalam mata kuliah Fisika Dasar II di perguruan tinggi adalah listrik. Konsep listrik berkaitan erat dengan kehidupan sehari-hari mahasiswa dan sering mereka gunakan dalam keseharian ataupun dalam kegiatan-kegiatan tertentu. Mahasiswa kerap menghadapi masalah mengenai listrik sehingga dapat diangkat basis dari suatu pembelajaran. Melalui penggunaan 
model pembelajaran experiential Kolb diharapkan mahasiswa mempelajari konsep listrik tidak hanya menghapal konsep-konsep saja tetapi mahasiswa secara aktif membangun sendiri pengetahuannya melalui pemecahan masalah. Dengan demikian pembelajaran yang digunakan dapat meningkatkan pemahaman konsep mahasiswa.

\section{METODE PENELITIAN}

Penelitian ini menggunakan metode kuasi eksperimen (eksperimen semu) dan deskriptif. Metode eksperimen semu digunakan untuk mengetahui perbandingan peningkatan pemahaman konsep antara mahasiswa yang mendapatkan pembelajaran dengan model experiential Kolb dan yang mendapatkan pembelajaran dengan model konvensional. Metode deskriptif digunakan untuk mengetahui gambaran tentang tanggapan mahasiswa terhadap model pembelajaran experiential Kolb yang diterapkan.

Desain eksperimen yang digunakan adalah "pretest-posttest control group design" (Sukmadinata, 2009:208) dimana penentuan kelas kontrol dilakukan secara acak perkelas. Kelas eksperimen dilakukan dengan memberikan perlakuan pembelajaran dengan model pembelajaran experiential Kolb dan kelas kontrol dengan model pembelajaran konvensional. Secara bagan, desain penelitian yang digunakan dapat digambarkan dalam Tabel 1.

Tabel 1: Desain penelitian

\begin{tabular}{|l|c|c|c|}
\hline Kelompok & Pretest & Perlakuan & Postest \\
\hline Eksperimen & $\mathrm{O}$ & $\mathrm{X}$ & $\mathrm{O}$ \\
\hline Kontrol & $\mathrm{O}$ & $\mathrm{Y}$ & $\mathrm{O}$ \\
\hline
\end{tabular}

Keterangan:

$\mathrm{X}=$ dikenakan perlakuan model pembelajaran experiential Kolb.

$\mathrm{Y}=$ dikenakan perlakuan model pembelajaran konvensional.

$\mathrm{O}=$ instrumen (tes tertulis pemahaman konsep)

\section{Populasi dan Sampel}

Populasi dalam penelitian ini adalah seluruh mahasiswa Teknik semester II yang terdiri dari enam kelas teknik pada salah satu
Universitas di Majalengka tahun ajaran 20132014. Sedangkan sampel dalam penelitian ini diambil satu kelas eksperimen dan satu kelas kontrol. Pengambilan sampel dilakukan dengan teknik simple random sampling karena pengambilan sampel secara acak tanpa memperhatikan strata yang ada dalam populasi (Sugiono, 2006: 57). Yaitu kelas Teknik Mesin IIA yang terdiri dari 33 mahasiswa sebagai kelas eksperimen dan kelas Teknik Informatika IID yang terdiri dari 31 mahasiswa sebagai kelas kontrol.

\section{HASIL DAN PEMBAHASAN Hasil Penelitian \\ 1. Peningkatan Pemahaman Konsep Mahasiswa}

Berikut ini perbandingan nilai pretest, posttest, dan nilai gain dinormalisasi antara kelas eksperimen dengan kelas kontrol sebagai berikut.

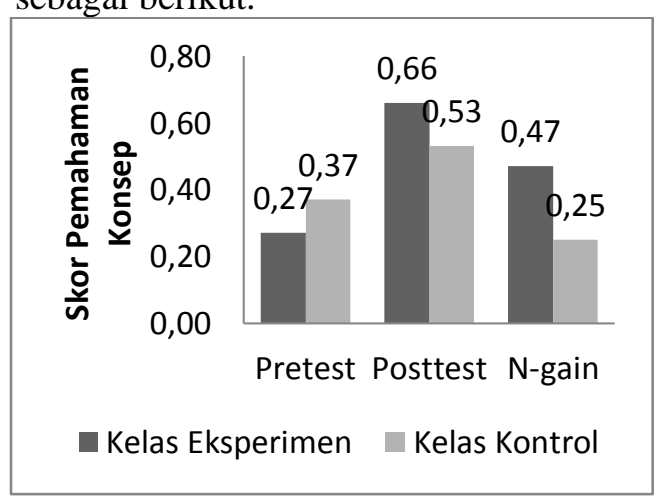

Gambar 1. Diagram Batang Perbandingan

Skor Rata-Rata Kelas Eksperimen dan Kelas Kontrol

Dari Gambar 1 di atas terlihat bahwa gain dinormalisasi kelas eksperimen lebih tinggi dari kelas kontrol. Nilai gain dinormalisasi untuk kelas eksperimen 0,47 dengan kategori sedang. Sedangkan nilai gain dinormalisasi untuk kelas kontrol 0,25 dengan kategori rendah.

Setelah melihat peningkatan pemahaman konsep dari gain dinormalisasi, perlu dilihat signifikansi dari perbedaan peningkatan tersebut. Sehingga akan diketahui apakah peningkatan pemahaman konsep dengan penggunaan simulasi virtual yang dikembangkan berbasis model eksperiential Kolb benar-benar signifikan dibandingkan dengan tanpa diperkaya simulasi virtual yang dikembangkan berbasis model eksperiential Kolb. 
Pada penelitian ini ada empat indikator pemahaman konsep menurut Bloom revisi Anderson yaitu menafsirkan, menarik inferensi, membandingkan, dan menjelaskan. Keempat indikator tersebut ditentukan gain dinormalisasi untuk melihat peningkatan tiap indikator pemahaman konsep. Nilai rata-rata gain dinormalisasi berdasarkan indikator pemahaman konsep untuk kelompok eksperimen dan kontrol ditunjukkan oleh Gambar 4.2.

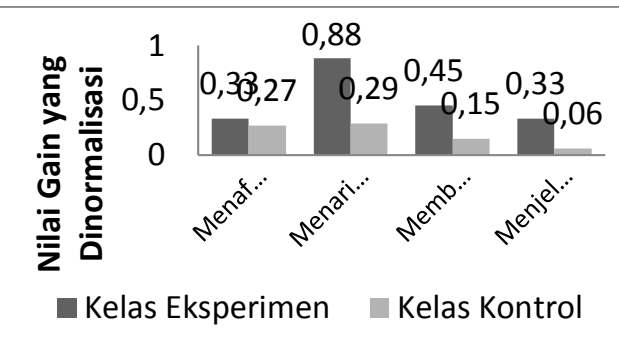

Gambar 2. Diagram Batang Perbandingan $\mathrm{N}-$ Gain Indikator Pemahaman Konsep

Untuk mengetahui signifikansi peningkatan tersebut, kita lakukan cara yang sama dengan uji hipotesis peningkatan pemahaman konsep.

Sehingga dapat disimpulkan penerapan model eksperiential Kolb dengan media virtual tidak secara signifikan dapat lebih meningkatkan kemampuan menjelaskan konsep listrik dinamis dibandingkan dengan penerapan model konvensional.

\section{Tanggapan Mahasiswa terhadap Model Pembelajaran Ekperiential Kolb}

Angket diberikan kepada mahasiswa bertujuan untuk mengetahui tanggapan mahasiswa terhadap penerapan model pembelajaran experiential Kolb. Angket ini terdiri dari 14 buah pernyataan dengan 4 kategori skor tanggapan. Untuk pernyataan positif kategori skornya yaitu Sangat Setuju (SS) dengan skor 4, Setuju (S) dengan skor 3, Tidak Setuju (TS) dengan skor 2 dan Sangat Tidak Setuju (STS) dengan skor 1. Sedangkan untuk pernyataan negatif, kategori skor tanggapannya adalah sebaliknya dari pernyataan positif. Angket ini diberikan pada kelas eksperimen diakhir pembelajaran.

Berdasarkan hasil perhitungan angket, sebesar $80 \%$ mahasiswa menyatakan setuju bahwa model pembelajaran experiential Kolb yang digunakan adalah model pembelajaran baru, $82 \%$ mahasiswa menyatakan bahwa cara dosen bertanya dapat memotivasi mahasiswa dalam mencari tahu jawaban, $83 \%$ mahasiswa menyatakan bahwa kegiatan diskusi membuat mahasiswa lebih menghargai pendapat orang lain. Sebesar $37 \%$ mahasiswa merasa model pembelajaran yang digunakan sama dengan model yang digunakan pada model pembelajaran sebelumnya, $40 \%$ mahasiswa menyatakan model pembelajaran experiential Kolb yang diterapkan membuat sulit dalam memahami konsep dan 38\% menyatakan bahwa pembelajaran secara keseluruhan sangat membosankan.

\section{Aktivitas Dosen dan Mahasiswa pada Pembelajaran Experiential Kolb}

Pada tiap tahapan dilatihkan pemahaman konsep, sehingga pada pertemuan pertama pemahaman konsep mahasiswa belum terlatih dengan sempurna. Pada pertemuan kedua dan ketiga mahasiswa mengalami kemajuan dalam pemahaman konsepnya maupun kemampuan menjelaskan fenomena fisis, hal ini karena mahasiswa sudah terbiasa dengan model pembelajaran yang diterapkan yaitu model pembelajaran experiential Kolb.

\section{Pembahasan \\ 1. Peningkatan Pemahaman Konsep Mahasiswa \\ Skor gain dinormalisasi memperlihatkan} lebih besar skor gain dinormalisasi pada kelas eksperimen dibandingkan kelas kontrol, dapat disimpulkan model eksperiential Kolb dengan media virtual lebih meningkatkan pemahaman konsep mahasiswa dibandingkan dengan penerapan model konvensional. Hal ini sesuai dengan yang diungkapkan Yezierski dan Birk (Kolomuc, 2012) yaitu 'untuk membantu mahasiswa memahami fisika dengan meningkatkan kemampuan mereka untuk memvisualisasikan proses hingga tingkat partikel yang terjadi pada tingkat mikroskopis'. Dengan meningkatnya kemampuan mahasiswa dalam memahami fisika maka soal-soal pemahaman konsep pun dapat dikerjakan lebih baik dari mahasiswa yang kurang meningkat pemahamannya tanpa simulasi virtual.

Setelah mahasiswa mampu memahami apa yang mereka pelajari, mereka tidak hanya mampu menyelesaikan soal-soal kompleks pemahaman konsep, merekapun dapat menerapkan pemahaman mereka pada masalah- 
masalah yang berkaitan dengan konsep fisika yang terjadi dalam kehidupan mereka seharihari. Menurut Anderson dan Krathwohl (2001) pada aspek pemahaman mahasiswa dituntut memahami atau mengerti yang diajarkan, mengetahui apa yang sedang dikomunikasikan dan dapat memanfaatkan isinya tanpa harus menghubungkan dengan hal-hal yang lain. Jadi tingkat kemampuan kognitif ini sangat mendasari kemampuan awal mahasiswa untuk mengembangkan kemampuan ranah kognitif lain yang lebih tinggi.

Penggabungan simulasi virtual ini dengan model pembelajaran eksperiential Kolb, memberikan dampak yang lebih baik lagi. Karena dengan pendekatan ini, mahasiswa mampu mengkonstruk pemahamannya sendiri, yang bisa membuat mahasiswa lebih memahami konsep. Dosen dapat memberikan kepada mahasiswa atau peserta didik anak tangga yang membawa mahasiswa akan pemahaman yang lebih tinggi, dengan catatan mahasiswa sendiri harus memanjat anak tangga tersebut (Slavin, 1995). Sehingga dosen disini hanya berperan sebagai fasilitator yang membimbing mahasiswa agar dapat menemukan sendiri pengetahuan-pengetahuan barunya.

Setelah mengetahui perbedaan peningkatan pemahaman konsep antar kelas, dilakukan uji statistik untuk melihat signifikansi dari perbedaan peningkatan pemahaman konsep tersebut. Setelah dilakukan langkah-langkah untuk menguji hipotesis, didapatkan nilai signifikansi 0,004 . Ini berarti nilai signifikansi tersebut lebih kecil dari $\alpha=0,05$. Hal ini menunjukkan $\mathrm{H}_{0}$ untuk hipotesis uji Mann Whitney ditolak dan $\mathrm{H}_{1}$ diterima.

Setelah dilakukan uji statistik untuk melihat signifikansi perbedaan peningkatan tiap indikator pemahaman konsep, didapatkan tidak terjadi peningkatan yang signifikan pada indikator kemampuan menafsirkan dan menjelaskan tetapi terjadi perbedaan peningkatan yang signifikan pada indikator kemampuan menarik inferensi dan membandingkan.

a. Menafsirkan

Menafsirkan adalah mengubah dari satu bentuk informasi ke bentuk informasi lainnya, misalnya dari kata-kata ke grafik atau gambar, atau sebailknya, dari kata-kata ke angka atau sebaliknya, maupun dari kata-kata ke kata-kata (Anderson, 2010). Dengan tidak signifikannya peningkatan kemampuan menafsirkan, terlihat bahwa simulasi virtual ini kurang optimal dalam menampilkan perubahan informasi dari data eksperimen ke grafik. Media simulasi virtual yang digunakan tidak menunjukkan proses pembuatan grafik berdasarkan kecenderungan data. Walaupun tidak signifikan, namun terlihat bahwa nilai gain dinormalisasi kelompok eksperimen lebih besar dari kontrol, sehingga simulasi virtual berpengaruh lebih baik dalam meningkatkan kemampuan menafsirkan.

b. Menarik Inferensi

Menarik inferensi adalah menemukan suatu pola dari sederetan contoh atau fakta (Anderson, 2010). Dengan signifikannya peningkatan kemampuan menarik inferensi, terlihat bahwa simulasi virtual ini dapat mengajak mahasiswa untuk mampu menarik inferensi dari fakta-fakta yang ada, misalnya dari fenomena yang mereka lihat. Media simulasi virtual yang digunakan meminta mahasiswa untuk menganalisis fenomena yang mereka lihat, kemudian menarik inferensi dari hal penting yang berhubungan dengan konsep listrik dinamis.

c. Membandingkan

Membandingkan adalah menemukan mendeteksi persamaan dan perbedaan yang dimiliki dua objek, ide, ataupun situasi. Dengan signifikannya peningkatan kemampuan menarik inferensi, terlihat bahwa simulasi virtual ini dapat menunjukkan pada mahasiswa persamaan dan perbedaan dua fenomena atau lebih secara bersamaan. Media simulasi virtual yang digunakan meminta mahasiswa untuk membandingkan fenomena yang mereka lihat, untuk mencari persamaan dan perbedaannya.

d. Menjelaskan

Menjelaskan adalah mengkonstruk dan menggunakan model sebab-akibat dalam suatu sistem. Dengan tidak 
signifikannya peningkatan kemampuan menafsirkan, terlihat bahwa simulasi virtual ini kurang optimal untuk menggambarkan sebab-akibat dari suatu fenomena yang dilihat mahasiswa. Media simulasi virtual yang digunakan kurang menunjukkan penyebab dari suatu fenomena listrik dinamis terjadi. Walaupun tidak signifikan, namun terlihat bahwa nilai gain dinormalisasi kelompok eksperimen lebih besar dari kontrol, sehingga simulasi virtual berpengaruh lebih baik dalam meningkatkan kemampuan menjelaskan.

Dari ekstrimnya nilai rata-rata gain dinormalisasi pada kemampuan menarik inferensi dan menafsirkan dikarenakan pemberian lembar kerja yang berbeda. Menarik inferensi bisa menjadi perbedaan yang paling tinggi karena dalam lembar kerjanya ditunjukkan simulasi virtual, kemudian diminta untuk menarik inferensi dari simulasi tersebut. Hal ini menyebabkan mahasiswa menjadi terlatih untuk dapat menarik inferensi dari suatu kejadian atau fenomena yang mereka lihat. Berbeda dengan kelas kontrol yang tidak diperlihatkan simulasi virtual, sehingga mereka tidak diminta untuk menarik inferensi dari sesuatu yang mereka lihat. Mereka hanya mendengarkan penjelasan dari dosen untuk mengganti simulasi virtual yang ditayangkan di kelas eksperimen. Sehingga mereka hanya membayangkan yang dijelaskan oleh dosen, tanpa bisa melihatnya secara nyata. Sedangkan kemampuan menafsirkan bisa menjadi kemampuan yang perbedaan kelas eksperimen dan kontrol tidak terlalu jauh dikarenakan dalam simulasi virtual kurang merepresentasikan perubahan bentuk suatu informasi. Misalnya seperti dalam soal pemahaman konsep tentang mengubah dari bentuk data ke grafik, hal ini tidak ditampilkan dalam simulasi. Hal ini membuat mahasiswa kelas eksperimen kurang meningkat kemampuan menafsirkannya, sehingga membuat jarak nilai gain dinormalisasi mendekati kelas kontrol.

\section{Tanggapan Mahasiswa terhadap Pembelajaran Experiential Kolb}

Berdasarkan hasil analisis angket tanggapan mahasiswa terhadap model pembelajaran experiential Kolb, dapat disimpulkan bahwa mahasiswa memberikan tanggapan positip (baik) terhadap model pembelajaran experiential Kolb yang diterapkan pada pembelajaran konsep listrik. Berdasarkan data yang diperoleh, sebesar $80 \%$ mahasiswa menyatakan setuju bahwa model pembelajaran experiential kolb yang digunakan adalah model pembelajaran baru, $82 \%$ mahasiswa menyatakan bahwa cara dosen bertanya dapat memotivasi mahasiswa dalam mencari tahu jawaban, $83 \%$ mahasiswa menyatakan bahwa kegiatan diskusi membuat mahasiswa lebih menghargai pendapat orang lain. Sebesar $37 \%$ mahasiswa merasa model pembelajaran yang digunakan sama dengan model yang digunakan pada model pembelajaran sebelumnya, $40 \%$ mahasiswa menyatakan model pembejalaran experiential Kolb yang diterapkan membuat sulit dalam memahami konsep dan 38\% menyatakan bahwa pembelajaran secara keseluruhan sangat membosankan.

Model pembelajaran yang diterapkan menurut mahasiswa sangat menyenangkan sehingga mahasiswa menjadi lebih termotivasi untuk belajar dan menginginkan agar dapat diterapkan pada pembelajaran materi yang lain. Tahap-tahap pembelajaran experiential Kolb mampu menggali pemahaman konsep dan melatih kemampuan menjelaskan fenomena fisis. Dengan demikian mahasiswa lebih termotivasi dalam belajar.

\section{DAFTAR RUJUKAN}

Dahar, R. W. (1989). Teori-Teori Belajar. Jakarta: Erlangga.

Depdiknas. (2006). Kurikulum Tingkat Satuan Pendidikan Sekolah Menengah Atas. Jakarta: Depdiknas.

Manolas, E.I. (2005). "Kolb's Experiential Learning Model: Enlivening Physics Courses inPrimary Education". The Internet TESL Journal. 3,(9)

Nur, Mohammad, dan Prima Retno Wikandari.(2000). Pengajaran Berpusat Kepada Mahasiswa Teknik Unma dan Pendekatan Konstruktivis dalam Pengajaran. Surabaya: UNESA Press. 
Robert, J.Y. dan Christopher, M.C. (1981).

Reflective Journal Writing: Theori and Practice". The Institute for research on Teaching Ericson Hall Michigan State University. 1-34.

Sanjaya, W. (2008). Strategi Pembelajaran Berorientasi Standar Proses Pendidikan. Jakarta: Prenada Media.

Sugiyono. (2006). Statistika untuk Penelitian. Bandung: Alfabeta.

Sukmadinata, N.S. (2009). Metode Penelitian Pendidikan. Bandung: PPS UPI dan Remaja Rosdakarya.

Dasar. Jakarta: Penataran Penyiapan Calon Penatar (PCP) Dosen PGSD-D II Guru Kelas. 